pp. 379-392

\title{
The Role of Accounting for the Innovation-oriented Organizations in Digital Economy
}

\author{
Submitted 23/08/19, 1st revision 19/09/19, 2nd revision 11/11/19, accepted 19/12/19 \\ E.A. Sharovatova ${ }^{1}$, I.A. Omelchenko ${ }^{2}$, E.P. Scherbakova ${ }^{3}$, \\ T.R. Martirosyan ${ }^{4}$, E.Yu. Demyanenko ${ }^{5}$
}

\section{Abstract:}

Purpose: The article aims to summarize the methodological approaches to the accounting and information segments selection, covering various groups of economic indicators, depending on external and internal factors affecting the business of innovation-oriented organizations.

Design/Methodology/Approach: For management purposes, management accounting capabilities are of increasing interest. However, the subjective approach of various authors to the characterization of management accounting tools and their implementation in practice does not make it possible to evaluate the real contribution of accounting to business management.

Findings: The authors proposed an accounting technique based on the accounting resource concentration in terms of significant for management information segments focused on the continuing innovative production feasibility decision-making in connection with the emergence of information about the business risk areas.

Practical implications: Such an approach will make it possible to more accurately assess the management objects' cost-effectiveness in relation to responsibility for incurring costs for each management segment, which corresponds to a similar object of management or accounting in management practice.

Originality/value: The main contribution of this study is the standardization of management accounting techniques for innovative production indicators.

Keywords: Management and commercial management, external and internal factors.

JEL Code: D24, M11, M21, M41.

Research Type: Research article.

\footnotetext{
${ }^{1}$ Doctor of Economics, Professor, Department of Accounting, Rostov State University of Economics, Rostov-on-Don, Russian Federation, esharovatova@mail.ru

${ }^{2}$ Ph.D., Associate Professor, Department of Accounting, Rostov State University of

Economics, Rostov-on-Don, Russian Federation, omelira@yandex.ru

${ }^{3}$ Ph.D., Associate Professor, Department of Accounting, Rostov State University of

Economics, Rostov-on-Don, Russian Federation, kosh_ka@bk.ru

${ }^{4}$ Postgraduate Student, Department of Accounting, Rostov State University of Economics,

Rostov-on-Don, Russian Federation, tigran-martirosy@mail.ru

${ }^{5}$ Ph.D., Associate Professor, Department of Accounting, Rostov State University of

Economics, Rostov-on-Don, Russian Federation, esharovatova@mail.ru
} 


\section{Introduction}

The features of the modern economy are characterized by the fact that large players on the trading platform are now focused on a high concentration of cash flows in their industry business. Unfortunately, in the context of the economy globalization, the factors leading the industry to financial instability have become more widespread. The most vulnerable in this process are economic entities that invest their own, rather than budgetary, funds into new technologies. Moreover, new technologies have not been tested yet in the market and have not reached the stage of mass production of new products. Undoubtedly, the consequences of globalization are accompanied by both positive and negative factors of influence on the global economy, leading to increased technological independence of some countries and its decrease in others.

However, there is no alternative to such a threat in modern world space, and therefore the focus in the management of entities participating in economic integration is the search for a rational mechanism of protection against financial risks. The desire for economic leadership explains the desire of capital holders to have a dominant influence on pricing the strategic raw materials for the country, the desire to strengthen the rating in order to participate in federal programs for the significant business development, to develop social programs in order to attract guaranteed budget sources to cover them, etc. At the same time, the turbulence of a market economy forces industry players to seek economic models for managing their business, including accountable models to achieve leadership in global economy in the long term.

Against this background, the characteristic features of accounting techniques, caused by the realities of the digital economy, which did not change the set of accounting elements, but had an impact on their practical implementation, are manifested. For example, primary documentation, as an accounting element, has not lost its significance for accounting purposes. However, in connection with automatic information "reading" from each primary document in software products, it became possible to broadcast it simultaneously to many users and for various purposes. A similar approach is implemented using the element "economic activity facts assessment", when the opportunity to automatically generate a different valuation object estimation to solve various management tasks: market value, actual, forecast, average and other type of valuation is laid. It became possible to maintain multi-level accounting when the elements "accounts and double entry" are implemented simultaneously in several accounting records, for example, in the system of accounting, tax and management accounting (Issakova et al., 2017).

At the same time, within the framework of the latter, information can be generated simultaneously on the disclosing accounts, for example, the costs of the product being produced, the costs of the business process, the costs of the structural unit — all this within the framework of a single business transaction involving various ciphers of accounts to form a dual, triple and more double entries. As a result, the digital 
economy has developed integrated accounting, aimed at diversified informativeness of the top managers and the decisions adoption at the time of transactions under the entrepreneurial activity conditions, not based on the interim results and even more, financial statements (Vokshi, 2018; Thalassinos and Liapis, 2014). The multi-user transformation of accounting elements with modern software products is inherent in both international and Russian management systems.

Innovation-oriented organizations, in which statistics have not yet been generated on the weighted average cost of manufactured products, sales of new products, value added, and sales profit should be manifested as the most interesting in the multi-user component of accounting. In order to secure this business, such accounting methodology should become relevant, providing offers for the most informative management set of techniques and accounting methods regardless of the managers' knowledge. The key method in this direction is the method of grouping information modules (segments) that can reveal the influence of each of them on the financial result of the company in conjunction with the responsibility of the manager for this result. The desire to protect themselves from economic risks forces innovativeoriented companies to make special requirements for management accounting, which is provided with recommended standards in international practice, but in Russia it does not have such support.

As a result, the pressure of market problems on the commercial entities economics leads to the need to concentrate the internal abilities of management to mitigate problems caused by the external factors, finding ways to minimize economic risks. Not the last role in this process is given to accounting segmentation of the information space, in which the managerial resource of each segment is responsible for solving an economic problem.

\section{Research Objectives and Hypotheses}

The aim of this work is to consider the main directions of expanding the accounting resource, as a part of commercial management, for innovation-oriented organizations and justify the obtained management accounting capabilities in the digital economy. Achieving selected goals requires solving the following tasks:

1) to identify the influence factors on the choice of accounting and analytical segmentation of innovation-oriented organizations;

2) to justify the influence of external and internal factors on business performance, depending on the construction of accounting and information segments;

3) to propose an algorithm for evaluating the results of accounting building management information of innovation-oriented organizations.

To solve the tasks in the study, the following hypotheses will be tested: 
H1: a risk-oriented environment of innovative production in a market economy requires a distinction between the information field of accounting and management accounting;

H2: the main approaches to the construction of accounting and information segmentation depend on the technological organization of production and the specifics of corporate management of this production.

\section{Literature Review}

The interest in innovatively oriented information segmentation techniques in conjunction with management accounting techniques has been revived by the Russian representatives of the economic school. The works of such domestic authors as M.A. Vakhrushina (2006), V.B. Ivashkevich (2003), A.A. Sokolov (2004) contributed to the effect knowledge of modern accounting segmentation, designed to protect the management style from economic risks. Contemporaries of the Russian scientific school in the field of accounting and management accounting enriched management with the applied techniques, contributing to the methods and practices understanding of organizing information support for various management segments. The famous works in this area were those by N.D. Vrublevsky (2005), V.E. Kerimov (2009), N.P. Kondrakov (2003), O.E. Nikolaev (1997), A.D. Sheremet (2000) and others. These authors contributed to understanding the methods of the accounting space transformation depending on the various needs of management.

Since the entrepreneurial activity intensification in Russia raises the requirements for a market-oriented management model, there is a demand for a standard set of information segments for revenue and profit management, which can be adapted to specific production and create a corporate segment architecture, providing it with industry-specific methods of budgeting, accounting, control and analysis. In the digital economy context, increased "attention to formalization in accounting is associated with its automation, the development of automated control systems" (Ivashkevich, 2000). In the Russian management practice, due to the lack of guidelines for organizing a typical structure of accounting and analytical segments, which are essentially a "tree of goals" for business, responsibility for its formation is either completely absent or lies with the chief accountant as a part of RAS 12/2010 execution "Information on segments" (RAS12/2010, 2010). As a result, the current practice of Russian accounting and analytical segmentation today does not fully possess the resource that will reveal the influence of each external and internal factor on the innovative production results' components.

\section{Research Methodology}

The general scientific methods, such as analysis, detail and generalization, comparison, observation, formalization, analogy, historical, logical and systemic approaches were used as research tools in this study implementation. 
The private methods of scientific knowledge, such as the method of constructing analytical tables, a method of schematically structuring information, and methods for evaluating economic information were used in the study.

\section{The Results of the Study}

The model of production and management innovative development in modern conditions is becoming a basic condition for the financial stability of the company. Against this background, business management today requires not only knowledge of the production technology components, but also management technology knowledge, in which techniques for segmenting information for management purposes play a special role. In this regard, the aim of this work was to generalize the main directions of accounting segmentation and analytical information in relation to commercial entities depending on the influence of significant internal and external factors on their economic efficiency. Achieving the chosen goals requires solving the following tasks:

$>$ to separate the factors of internal and external impact on the accounting organization and analytical support for economic entities;

$>$ to summarize the methods of choosing accounting segments depending on external and internal factors affecting the business.

Since the accounting segmentation structuring is dependent on various management needs, this presents its own requirements for the accounting methods choice in relation to intermediate business results affecting its final profit. In turn, this contributes to the emergence of interest in cost processes in relation to various accounting objects that are a part of an information segment. For example, when examining the territorial dispersion of sales, the object of interest for managers becomes information, firstly, about the share of sales on a territorial basis, and secondly, about the sales' profitability on the same basis, which together will allow the more profitable costoutput combinations formation. It is possible to give an example of the managers interest manifestation in identifying the most profitable customers in terms of alternative approaches of customers to the prepayment share. Some customers are willing to pay $100 \%$ prepayment, others less than $50 \%$, others - on the terms of payment after the order execution. By grouping the stable customers in three information segments by prepayment levels, it is possible to manage cash flows based on budget and actual data on cash flows. Or, for example, the top managers' ability to manage their area of responsibility for specific indicators leads to the need to divide all economic information into business processes, which, together with budget indicators, will make it possible to assess their managerial competencies.

Thus, taking into account the multifactorial influence on the choice of management system in conditions of risky production, creating a standard approach to the choice of segmenting accounting information for each possible factor of influence on the choice of managerial decision of managers is of no doubt advisable. At the same time, 
a number of requirements for such accounting and management technologies in the global economy of the XXI century can be distinguished as:

- Creative ideas of intellectual capital, manifested in new technologies and rapidly replacing each other, also calls for swiftly monitoring any idea implementation effectiveness, from the appearance of its concept to the start of mass production. This obliges to search for an option of economic security and evaluation of each production process's indicators, which is possible under the conditions of setting up management accounting for the detailed segmentation in accounting for production costs.

- It is advisable to consider the fact that the capital owners claim a substantial share in profits when selling products after the mass production start in the context of the management's administrative resource. This obliges top managers to systematically optimize costs and predict a positive margin from sales, which also directs management to more advanced methods of cost management and full responsibility for each managerial action.

- Management technologies become popular in business if management focuses not only on strategic indicators (target sales and profits, other entities participating in the business, planned level of investments, etc.), but also on a business model based on options dependencies sales:

a) with possible profit options;

b) with possible motivational policy options;

c) with a possible social subject's status.

All this implies a matrix approach to the use of accounting and management technologies, capable of building the relationship of different sales, costs and results levels against the background of different statuses of economic segments. World knowledge in the field of management allows us to recognize the braking factors of modern production, since the innovations of modern startups deliberately become an object of interest for competitors looking for an option to slow down the introduction of new technologies, especially at the initial stage. Such inhibition factors become dangerous, for example, the absence of a stimulating management system for management participants, the characteristic features of which are vague responsibility for intermediate management results, lack of accounting and analytical resource capable of diagnosing early risks, belittling the role of counterparties in intentionally attracting financial risks, etc.

As a result, the presence of external factors affecting the business, such as territorial sales dispersion, customer preferences regarding prepayments, market readiness for the various goods and services consumption etc., actualizes internal factors affecting the subject's information space structuring. There is a need for a special construction of information segments in management accounting, which will make it possible to evaluate the performance of a business in various areas of activity. 
The unpredictability of modern economic and political systems in the global community changes the demands of the managers' regarding methods for collecting management information. The modern technique, on the one hand, must take into account the influence of external factors on the algorithm for generating accounting and analytical information, on the other hand, it must respond to the requests from internal managers and disclose information about various information segments contributing to assessing the performance of the business and its individual parts. At the same time, the pressure of external factors, as a driving force for strengthening business on an external trading platform, most of all determines the management strategy and the corresponding information segments. The pressure of internal factors, as the driving force for strengthening the managers' competencies, first determines management tactics and allows to evaluate the participation of top managers in the total profit of the organization. From these positions, a set of external and internal factors affecting the organization of segmentation when choosing a strategic and tactical management model is shown schematically in Figure 1.

Figure 1. External and internal factors affecting the choice of accounting segments in the organization
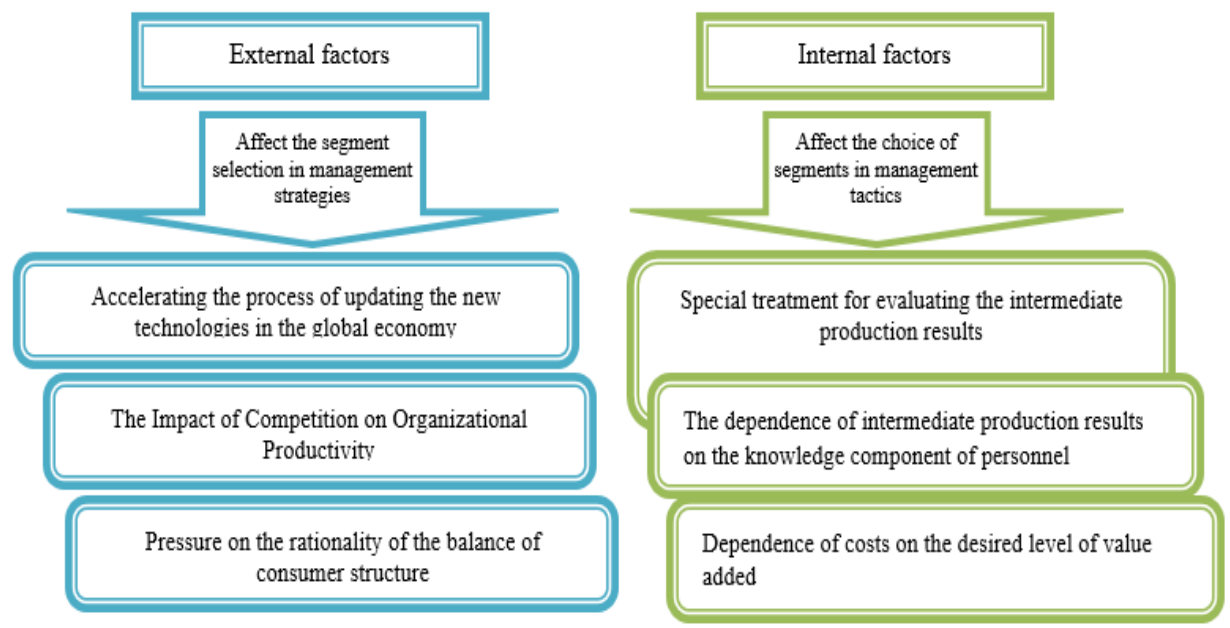

The presence of various factors affecting the innovative activities' effectiveness, calls for organizing the information segmentation in the strategic and tactical management accounting system in such a way as to minimize the risks of added value loss for various external and internal reasons.

Note that information segmentation is inherent in accounting, which is reflected in Russian practice at the legislative level. So, in accordance with clause 6 of FAS 12/2010 "Information on Segments" (FAS12/2010, 2010) four areas of detail are distinguished: manufactured products, purchased goods, work performed, services rendered, main buyers (customers) of products, goods, works, services, geographical 
regions in which the activity is carried out and the organization structural units. From the position of financial accounting, the segment allocation is impractical if the revenue in this direction is less than $10 \%$. This approach is quite adequate for disclosing information in the preparation of financial statements but is insufficient from the point of view of management aimed at maximizing financial results, involving the high-risk innovative projects implementation.

As noted by Ivashkevich (2016) "In recent years, management accounting has significantly expanded the range of enterprise management tasks that can be solved on its basis" and, above all, in terms of satisfying a variety of diverse information requests. As for the development of an external strategy for innovative development, in our opinion, the following information segments in management accounting are:

- areas of activities with detailing for each of them sales, costs and financial results in order to select the most cost-effective activities;

- the distribution of income, expenses and financial results on a territorial basis with the aim of reorienting the business to a more promising sale market;

- sales structuring according to seasonality in order to find the most productive period to intensify the activities;

- structuring of income by financing sales sources in the context of commercial or budget customers in order to conduct a qualitative analysis of the payment obligations and reorientation fulfillment guarantee to guaranteed customers.

As a result of the external environment aggression and, accordingly, external factors, strategic management accounting is aimed at creating a business model of the organization focusing on the strategy of profitability and efficiency. However, tactical management accounting, in which the separation of segments is no longer focused on profitability as much as on the cost of each participant in production and management, on its marginal contribution to total profit and other internal indicators of value, is no less important. In this regard, the management accounting techniques for developing internal development tactics and the information segments, in our opinion, are:

- areas of financial responsibility for the organization costs in accordance with its functional management structure;

- cost centers in accordance with the linear management structure;

- technological processes of production and auxiliary processes for servicing the main production;

- commodity groups or individual commodity units (works, services) in the form of finished products for use by the consumer.

In aggregate, the indicated segments of management accounting are called upon to ensure internal control of the costs close to the places of their occurrence in conjunction with responsibility for their level, as well as to facilitate budgeting in the context of all reproduction participants. 
Thus, in our opinion, the deepening of world capital integration, the unification of world experience in new technologies, the formation of a production infrastructure sensitive to economic and political crises, the unification of standards and rules in the pursuit of transparency in financial transactions and other consequences of the globalization of the economy have led to the need to create an adequate information management system support. In conditions of a multiple increase in the amount of data induced by a huge number of information systems, the most important task of management accounting is the accounting resource segmentation, focused on the narrowly focused information support of a manager.

Figure 2. The information segmentation structure in financial and managerial accounting



When segmenting the management accounting data, it is extremely important for a company focused on innovative development to achieve a balance between the intention to deepen the details of accounting information, which complicates the process of collecting and analyzing it, and the principle of the economic information marginal cost, which assumes that the cost of obtaining additional data should not exceed the economic effect of their use. From these positions, we have formed the information segmentation structure in financial and managerial accounting (Figure 2).

It is possible to propose a process of information segmentation for the purposes of strategic and tactical management accounting and control over the results obtained in terms of innovation-oriented production. We have developed a multi-level structure of accounting segments within the framework of management accounting, focused on the management tactics of innovative production. It is tactical management accounting primarily relevant for innovative production today because mass production has not started yet, and the sales strategy will be relevant again after the products prototypes' completion. 
When choosing the accounting segments for the innovative activities' management, it is advisable to create several levels of accounting software for the sequential dispersal of the "innovative production" cost of business process into administrative units (topdown). The levels may vary depending on the knowledge of the innovative enterprise possess managers. One of the most detailed options may be a five-level approach to information segmentation in the following areas: business process "Innovative Production"; targeted innovations; technology innovation; cost centers; innovative products. Each segment is characterized by the individual objects of management accounting, a calculation unit associated with it, and obtained effective management information. Table 1 presents the characteristic features of each information segment for the enterprises focused on innovative production.

Table 1. The accounting segmentation structure in the innovation-oriented production conditions (Martirosyan, 2015)

\begin{tabular}{|c|c|c|c|c|}
\hline Level & $\begin{array}{c}\text { Segmentation } \\
\text { level name }\end{array}$ & $\begin{array}{l}\text { Accounting } \\
\text { Objects }\end{array}$ & Calculated Unit & Expected effect \\
\hline $1^{\text {st }}$ level & $\begin{array}{l}\text { Buisness } \\
\text { process } \\
\text { "Innovative } \\
\text { production" }\end{array}$ & $\begin{array}{l}\text { Responsibility } \\
\text { Center }\end{array}$ & $\begin{array}{c}\text { Area of } \\
\text { responsibility }\end{array}$ & $\begin{array}{l}\text { Making management } \\
\text { decisions on the } \\
\text { effectiveness of the } \\
\text { functionality of the } \\
\text { business process and its } \\
\text { top manager }\end{array}$ \\
\hline $\begin{array}{l}2^{\text {nd }} \\
\text { level }\end{array}$ & $\begin{array}{c}\text { Target } \\
\text { Innovation }\end{array}$ & $\begin{array}{l}\text { Innovative } \\
\text { directions }\end{array}$ & $\begin{array}{l}\text { Innovative } \\
\text { program }\end{array}$ & $\begin{array}{l}\text { Assessment of the } \\
\text { targeted innovation } \\
\text { programs effectiveness } \\
\text { and their profitability }\end{array}$ \\
\hline $\begin{array}{c}3^{\text {rd }} \\
\text { level }\end{array}$ & $\begin{array}{l}\text { Technological } \\
\text { innovation } \\
\text { stages }\end{array}$ & $\begin{array}{l}\text { Technological } \\
\text { stages }\end{array}$ & Stage & $\begin{array}{l}\text { Conformity assessment } \\
\text { of the budget cost of } \\
\text { each stage in the work } \\
\text { schedule to actual } \\
\text { indicators }\end{array}$ \\
\hline $4^{\text {th }}$ level & Cost centers & Structural units & $\begin{array}{l}\text { Technological } \\
\text { process }\end{array}$ & $\begin{array}{l}\text { Assessment of each } \\
\text { cost center share in the } \\
\text { total cost of innovative } \\
\text { production }\end{array}$ \\
\hline $5^{\text {th }}$ level & $\begin{array}{l}\text { Innovative } \\
\text { products }\end{array}$ & $\begin{array}{l}\text { Commodity } \\
\text { production }\end{array}$ & Commodity unit & $\begin{array}{l}\text { Assessment and } \\
\text { analysis of using equity } \\
\text { for innovative products } \\
\text { appropriateness }\end{array}$ \\
\hline
\end{tabular}

In accordance with the corporate policy for the commercial entity development, the number of information segments and their economic parameters can be changed depending on the management goals. As the intermediate cost is formed, it becomes possible in the early stages of production to evaluate the invested costs effectiveness even before the final output. At the same time, the key component of management is 
the ability to structure all the indicators in the context of responsible managers for each economic segment with accounting segmentation.

The accounting information assessment and its management analysis based on selected accounting segmentation is a target management tool. It is undeniable that the value of such information increases many times over for organizations developing new production and do not have statistics on estimated indicators. The desire to improve the methodology of management appraisal is no longer an innovation for commercial management, and its evolution started long before the market environment adaptation. The new production costs can be estimated from the perspective of an engineering approach considering the new products' technical and technological characteristics and based on the costs and activity volumes magnitude data in the past periods using economic and mathematical methods of correlation analysis. Management analysis using the segment information about the value of fixed and variable costs allows to determine:

- the volume of various sales segments in quantitative and total terms, ensuring breakeven operation of the enterprise;

- the amount of marginal and gross profit from the new products sale;

- the influence of factors changing the new products quantity and the costs of their production as well as the sale on the financial organization results as a whole;

- strategic directions in changing the pricing policy for new products, the limits of increasing or decreasing prices and tariffs;

- the value of additional production and sales with an increase in the costs of organizing and managing new production.

For example, a commercial organization during the reporting period, in addition to the usual serial production, sells 3,000 new products at a price of 1,500 p for a unit. According to management accounting, direct (variable) costs of materials and wages for one product are $1200 \mathrm{p}$, constant incremental (due to the emergence of new production) expenses of the period $600000 \mathrm{p}$. Rent of additional retail space will cost 90000 p. Based on the analysis of these data, we determine:

1. The volume of sales, providing a break-even threshold of profitability for new products:

a) in quantitative terms

$$
X o=\frac{600000}{1500-1200}=2000 \text { (unit) }
$$

b) in terms of value



2. The amount of profit received from the products sale $(\mathrm{PR})$ is equal to: $\mathrm{PR}=$ $1500 \times 3000-600000-1200 \times 3000=300000(\mathrm{p})$ 
3. In the next reporting period, the company plans to receive $450,000 \mathrm{p}$ additional profit. If the previous conditions of new production and sales remain, it must additionally sell 500 products: $450000=1500 x-600000-$ $1200 \mathrm{x}$

$\mathrm{x}=3500$ unit.; $\Delta \mathrm{x}=3500-3000=500$ (unit)

4. In order to increase profit by $30,000 \mathrm{p}$ with the same sales volume, it is necessary to increase the price of a new product (p) by 10 rub.:

$300000+30000=3000 \mathrm{p}-600000-1200 \cdot 3000$

$\mathrm{p}=1510$ rub. $\Delta \mathrm{p}=1510-1500=10(\mathrm{p})$

5. With the planned reduction of variable costs and product prices by $10 \%$ while reducing fixed costs by $100,000 \mathrm{p}$, the company will receive the additional profit:

$P R=1350 \times 3000-1080 \times 3000-500000=310000(p)$

The company's profit increases by $10,000 \mathrm{p}$ while maintaining the same sales volumes. However, lowering the price of the product can contribute to further growth in sales of products, and hence profits. This makes the planned activities fully justified.

6. If, having reduced the price by $10 \%$, the company is able to further sell 500 new products, the financial result of sales will be:

$\mathrm{PR}=1350 \cdot(3000+500)-1200(3000+500)-600000=-75000(\mathrm{p})$

As a result, the company will receive a loss of 75,000 p. A possible increase in new products sales is not enough to compensate for the loss in price. If the price is reduced by $150 \mathrm{p}$ break-even, the sales should be at least 4000 units:



7. Lease of additional retail space becomes justified with an increase in sales



The above calculations show the results of the analysis using the zero-profit point indicators. This is the sales value in physical or monetary terms, at which the variable and fixed costs incurred in connection with the new production are fully covered by the proceeds from the sale of new products. The level of financial security and the organization financial strength depends on the difference size between the break-even and the maximum possible or achieved sales. It can be expressed in the value of liquid for the sale of goods and services. The financial strength stock is characterized by the volume of goods in quantitative and value terms, which the company hopes to sell in excess to the volume ensuring break-even sales. The less significant this value, the 
lower the level of financial security, the higher the risk of under-coverage of fixed costs, and therefore the loss-making of the enterprise.

One of the most common indicators in management analysis of new production segments is the marginal income ratio to sales revenue. On its basis, the minimum volume of product sales under various conditions and the dynamics of changes in fixed and variable costs is determined, the effectiveness of production and marketing activities of the enterprise is evaluated. The high value of this coefficient and its growth indicates a fairly efficient organization work and its positive dynamics, but at the same time a significant dependence of performance on sales. If the demand for products or other goods of such an enterprise is subjected to fluctuations, its management must constantly look for additional sources of income, for example, from financial investments in other business, putting part of its own property into shortterm and long-term leases.

In conditions of new production, when calculating the break-even point, the volume of production and sales are considered as the only factors in the change of costs. Meanwhile, in real life, they depend on a number of other financial and non-financial parameters. All this limits the scope of breakeven analysis based on the marginal approach to situations where the most important indicators and their determining factors, for example, the value of overhead costs and unit costs per unit of output and its price are constant, which is practically possible only in the short term. Management is largely based on the identification and analysis of deviations from predetermined parameters for each segment of production, sales and achieved results. Without the analysis of the deviations' content and structure, it is impossible to determine the causes and identify the culprits of negative deviations or persons, factors and circumstances to which these deviations can be credited. It is on the deviations analysis basis in the middle of the last century that the theory and practice of deviation control was formed and developed. As a result, the assessment and management analysis of management reporting indicators is wide in scope of the enterprise varieties, their economic problems, types of assets and operations with them. All managerial decisions, one way or another, are based on the economic analysis results and should consider the human factor of the possibilities of their implementation. Each manager is called to be an analyst of management accounting information, a user of the results of its analysis.

\section{Conclusion}

Thus, the unpredictability of production external and internal factors, and even more in the new production conditions, obliges to abandon the accounting space organization in accordance with national accounting regulations. The accounting segmentation organization, depending on the revenue and expenditure indicators distribution, depending on participation in serial or new production, becomes more effective for commercial management purposes. This was justified in Figure 1 which 
presents external and internal factors affecting the choice of accounting segments in the organization, and Figure 2 which presents the example of the information segmentation structure in financial and managerial accounting.

Detailing of accounting information depending on external and internal factors affecting production results allows more efficient use of the results economic assessment and management analysis possibilities. It becomes possible to carry out marginal analysis based on the breakeven point calculation, to analyze the indicators considering changes in the income and expenses components for each production segment and sales. At the same time, the organization of accounting segmentation can be flexibly rebuilt depending on the corporate approach to the production organization and the sales segments choice.

\section{References:}

FAS12/2010. 2010. Federal accounting standard "Information on segments" 12/2010, Available at: http://www.consultant.ru/document/cons_doc_LAW_107913.

Issakova, S.A., Moldabekova, A.S., Kenzhebayeva, M.T., Alibekova, V.N., Tuleyeva, G.T. 2017. Preparing consolidated financial statements in accordance with IFRS.

European Research Studies Journal, 20(3), 458-469.

Ivashkevich, V.B. 2000. External and internal factors of formalization of the methodology of financial accounting. Formalization as the basis of the digital economy, materials of the All-Russian Scientific and Practical Conference with international participation, dedicated to the 75th birthday and 50th anniversary of the scientific and pedagogical activity of the Honored Economist of the Russian Federation, Doctor of Economics, Professor S. Hovhannisyan, 136-140.

Ivashkevich, V.B. 2003. Accounting management accounting. Moscow, Economist, 618.

Ivashkevich, V.B. 2004. Problems of the theory of management accounting and controlling. International Accounting, 14, 32-46.

Kerimov, V.E. 2009. Accounting management accounting. Moscow, 477.

Kondrakov, N.P. 2003. Accounting management accounting. Moscow, INFRA-M, 368.

Martirosyan, T.R. 2015. The main approaches to the selection of accounting objects in the innovation management system. Accounting and Statistics, 2(38), 7-14.

Nikolaev, O.A. 1997. Management accounting. Moscow, publishing house URSS, 368.

Sheremet, A.D. 2000. Management accounting. Moscow, FBK PRESS, 434 p.

Sokolov, A.A. 2004. Accounting for the segments of a commercial organization. Moscow, Finance and statistics, 288.

Thalassinos, I.E. and Liapis, K. 2014. Segmental financial reporting and the internationalization of the banking sector. Chapter book in, Risk Management: Strategies for Economic Development and Challenges in the Financial System, (eds), D. Milos Sprcic, Nova Publishers, 221-255, ISBN: 978-163321539-9; 978163321496-5.

Vokshi, N.B. 2018. The Connection between Accounting and Taxation from the Perspective of Preparing the Financial Statements. International Journal of Economics and Business Administration, 6(4), 34-47.

Vakhrushina, M.A. 2006. Management accounting. Moscow, Omega-L, 576.

Vrublevsky, N.D. 2005. Accounting management accounting. Moscow, Accounting, 400. 